antigens in insulin-dependent diabetes to the protein tyrosine phosphatase-like molecule IA-2 (ICA512). J Clin Invest 96: 1506-1511

3. Lu J, Li Q, Xie $\mathrm{H}$ et al. (1996) Identification of a second transmembrane protein tyrosine phosphatase, IA-2 $\beta$, as an autoantigen in insulin-dependent diabetes mellitus: Precursor of the $37 \mathrm{kDa}$ tryptic fragment. Proc Natl Acad Sci USA 93: 2307-2311

4. Notkins AL, Maclaren NK, Wasserfall C, Lan MS (1995) IA-2, a transmembrane protein of the protein tyrosine phosphatase family, is a major autoantigen in IDD. Autoimmunity 21: 49 A118 (Abstract)

5. Leslie RDG, Hawa M, Rowe W et al. (1995) Antibodies to a tyrosine phosphatase-like molecule precede and predict IDDM: an identical twin study. Autoimmunity 21: 60 A230 (Abstract)

6. Rossini AA, Handler ES, Mordes JP, Greiner DL (1995) Animal models of human disease. Human autoimmune diabetes mellitus: lessons from BB rats and NOD mice. Clin Immunol Immunopathol 74: 2-9

7. Lu J, Notkins AL, Lan MS (1994) Isolation, sequence and expression of a novel mouse brain cDNA, mIA-2, and its relatedness to members of the protein tyrosine phosphatase family. Biochem Biophys Res Commun 204: 930936
8. Passini N, Larigan JD, Genovese S, Appella E, Sinigaglia F, Rogge L (1995) The 37/40 kilodalton autoantigen in insulin-dependent diabetes mellitus is the putative tyrosine phosphatase IA-2. Proc Natl Acad Sci USA 92: 9412-9416

9. Bottazzo GF, Florin-Christensen A, Doniach D (1974) Islet-cell antibodies in diabetes mellitus with autoimmune polyendocrine deficiencies. Lancet ii: $1279-1283$

10. Palmer JP, Asplin CM, Clemons P et al. (1983) Insulin antibodies in insulin-dependent diabetics before insulin treatment. Science 222: 1337-1339

11. Baekkeskov S, Landin M, Kristensen JK et al. (1987) Antibodies to a $64,000 \mathrm{Mr}$ human islet cell antigen precede the clinical onset of insulin-dependent diabetes. J Clin Invest 79: 926-934

12. Atkinson MA, Maclaren NK (1988) Autoantibodies in nonobese diabetic mice immunoprecipitate $64,000-\mathrm{Mr}$ islet antigen. Diabetes 37: 1587-1590

13. Baekkeskov S, Dyrberg T, Lernmark A (1984) Autoantibodies to a 64-kilodalton islet cell protein precede the onset of spontaneous diabetes in the BB rat. Science 224: $1348-1350$

14. Markholst H, Klaff LJ, Kloppel G, Lernmark A, Mordes JP, Palmer J (1990) Lack of systematically found insulin autoantibodies in spontaneously diabetic BB rats. Diabetes 39: $720-727$

\section{Mortality of childhood-onset IDDM patients in Estonia}

Dear Sir,

Insulin-dependent diabetes mellitus (IDDM) leads to excess risk of mortality in developed countries even today [1]. Virtually no data are available on the mortality of IDDM patients in eastern Europe apart from a report from former East Germany on insulin-treated patients [2]. We report the mortality among childhood-onset IDDM patients from Estonia which until 1991 was a constituent republic of the former Soviet Union.

Patients were taken from the Estonian population-based childhood-onset IDDM registry which since 1980 has collected information on newly diagnosed cases aged $0-14$ years [3]. Between 1 January 1980 and 31 December 1989340 children were diagnosed with IDDM in Estonia. Registration of cases during 1980-1989 was estimated to be at least $95 \%$ complete using the capture-mark-recapture approach.

The survival status of this cohort was determined as of 1 January 1992. Attending physicians were asked to note the last date when the patient had visited the office or had been hospitalized. Additional information was obtained from currency exchange lists. Currency exchange took place in Estonia in June 1992 and those on the list had to be alive on 1 January 1992. In a minority of cases untraceable by these methods, telephone interviews were conducted and/or the cases traced by mail. Follow-up information was available on 339 cases $(99.7 \%)$. The only untraceable case was censored 1 week after diagnosis as the possibility of death of the patient was excluded. Seven subjects had emigrated and were censored at

Corresponding author: T. Podar, MD, Hospital of Endocrinology, Pikk 64, EE-2400 Tartu, Estonia the date last known to be alive. Since information on death certificates is known to be imprecise [4], the cause of death in each case was determined by careful review of hospital records and interviews with physicians and relatives by one of the investigators (T.P.). Background data on the mortality of the population of Estonia were obtained from the Department of Epidemiology and Biostatistics, Institute of Experimental and Clinical Medicine. Life-table analysis was used for the assessment of the survival of the cohort. Standardized mortality ratios (SMR) were computed using the computer package PersonYears [5]. 95\% confidence intervals (CI) of SMRs were calculated assuming the Poisson distribution.

The mean duration of follow-up was 6.1 years (range 012). The oldest possible attained age was 26 years. During the follow-up $10(2.95 \%)$ individuals died, seven male and three female. The crude mortality rate among the cohort was 425 per 100000 person-years. The 10 -year cumulative mortality of the cohort was high at $6.1 \%$. The overall SMR (all causes) for the age group 0-29 years was 5.01 (95\% CI 2.41-9.22) (Table 1). SMRs for males and females were similar and nonEstonians tended to have a somewhat higher SMR than Estonians $(8.85(95 \%$ CI $1.82-25.84)$ vs 3.50 (95\% CI 1.40 7.21), respectively).

Deaths were most often due to diabetic ketoacidosis, the main killer of the pre-insulin era, which accounted for $50 \%$ of deaths, four in males $(57 \%)$ and one in females (33\%). One male died from diabetic ketoacidosis at the onset of IDDM. One female was found dead in bed which could have been related to an acute diabetic complication but the possibility of suicide could not be excluded. One male and one female died because of cancer and two males in motorvehicle accidents. Careful investigation of the circumstances of the accidents revealed that in neither case was diabetes the cause. No deaths were due to chronic complications of IDDM or cardiovascular disease.

Despite the small size of the cohort and small number of deaths, these data should give an adequate estimate of the 
Table 1. Standardized mortality ratios (SMR) and $95 \%$ confidence intervals (95\% CI) in Estonian childhood-onset IDDM cohort subgroups

\begin{tabular}{llrrrrrr}
\hline Study group & $\begin{array}{l}\text { Age range } \\
\text { (years) }\end{array}$ & $n$ & Person years & Observed & Expected & SMR & 95\% CI \\
\hline Estonian males & $0-29$ & 129 & 898.1 & 4 & 1.011 & 3.96 & $1.08-10.12$ \\
Non-Estonian males & $0-29$ & 52 & 360.0 & 3 & 0.423 & 7.09 & $1.46-20.71$ \\
Estonian females & $0-29$ & 117 & 797.0 & 1 & 0.417 & 2.40 & $0.06-13.35$ \\
Non-Estonian females & $0-29$ & 42 & 297.1 & 2 & 0.142 & 14.06 & $1.70-50.79$ \\
Males & $0-29$ & 181 & 1258.1 & 7 & 1.435 & 4.88 & $1.96-10.05$ \\
Females & $0-29$ & 159 & 1094.1 & 3 & 0.560 & 5.36 & $1.11-15.67$ \\
Total & $0-29$ & 340 & 2352.2 & 10 & 1.994 & 5.01 & $2.41-9.22$ \\
\hline
\end{tabular}

mortality from childhood-onset IDDM in Estonia. Mortality of the total population of Estonia has been found to be considerably higher than in the developed countries bordering the Baltic Sea [6]. Compared to the background population, the survival of childhood-onset IDDM patients in Estonia is clearly inferior to that of Finland, Sweden, Norway, Israel and Allegheny County (USA) $[1,4,7]$, where the SMR is around 2, but better than in Japan (SMR close to 10) [1]. The mortality of IDDM patients has recently been shown to decline [7] and the Estonian cohort was diagnosed later than those in the above-cited studies.

Most deaths due to diabetic ketoacidosis could have been prevented with better patient education and more resources for self-monitoring. Blood glucose self-monitoring was almost non-existent in Estonia until the end of the 1980s. Patient education was neglected in the former Soviet Union as physicians were thought to be entirely responsible for the health of the patients. The role of the patients themselves in the treatment of IDDM was underemphasized. Eliminating the five deaths clearly due to diabetic ketoacidosis would have reduced the SMR two-fold, to 2.50 (95\% CI 0.81-5.83) similar to levels in Finland and Sweden, and not significantly different from that of the background population. However, the childhood-onset IDDM cohort also seems to be at increased risk for premature death from non-diabetes related causes.

The incidence rates of IDDM in the Baltic region range from 34 in Finland to 10 in Estonia to 6 per 100000 per year in Poland, Lithuania and Latvia [8]. Such a large variation has not yet been explained. The relatively small size of the pool of genetically susceptible individuals in the former socialist countries because of the higher numbers of patients dying before reproduction might be a contributing factor.

Our results demonstrate an alarmingly high proportion of deaths due to diabetic ketoacidosis and inferior survival of childhood-onset IDDM patients from an eastern European country.

Yours sincerely,

T.Podar, A.Solntsev, M.Rahu, M.Leinsalu, J.Tuomilehto, R.E.LaPorte

\section{References}

1. Diabetes Epidemiology Research International Mortality Study Group (1991) Major cross-country differences in risk of dying for people with IDDM. Diabetes Care 14: 49-54

2. Michaelis D, Jutzi E (1990) Trends in mortality rates in the diabetic population of the GDR. Exp Clin Endocrinol 95: 83-90

3. Podar T, Tuomilehto-Wolf E, Tuomilehto J, LaPorte RE, Adojaan B (1992) Insulin-dependent diabetes mellitus in native Estonians and immigrants to Estonia. Am J Epidemiol 135: $1231-1236$

4. Sartor G, Nystrom L, Dahlquist G (1991) The Swedish Childhood Diabetes Study: a seven-fold decrease in shortterm mortality? Diabet Med 8: 18-21

5. Coleman MP, Hermon C, Douglas A (1989) Person-Years. A Fortran program for cohort study analysis

6. Wedel H, Nilsson PEW (1992) High mortality in the Baltic states. SVEPET 4: 3-4

7. Joner G, Patrick S (1991) The mortality of children with type 1 (insulin-dependent) diabetes mellitus in Norway, 1973-1988. Diabetologia 34: 29-32

8. Tuomilehto J, Podar T, Brigis G et al. (1992) Comparison of the incidence of insulin-dependent diabetes mellitus in childhood among five Baltic populations during 1983-1988. Int J Epidemiol 21: 518-527

\section{Abnormal protein redox status in the lens and vitreous of diabetic subjects}

\author{
Dear Sir, \\ Considerable evidence indicates that structural changes of pro- \\ teins may be considered among the basic mechanisms leading \\ to cell damage and tissue modification [1]. It has been sug- \\ gested that increased release of free radicals and consumption
}

Corresponding author: E. Altomare MD, Istituto di Clinica Medica I, Università di Bari, Piazza G. Cesare 11, 70124 Bari, Italy of antioxidant compounds may be responsible for an increased lipid peroxidation in patients with poorly controlled diabetes mellitus [2], which in turn may contribute to the development of cataract associated with retinal disease [3]. Despite the high protein concentration in the lens and vitreous and its important structural role, little is known about the protein redox status in the lens and vitreous in diabetes.

We evaluated the protein oxidation process in cataractous lenses and vitreous of diabetic and non-diabetic patients and in healthy subjects, by measuring the levels of sulfhydryl proteins, protein-bound sulfhydryls and carbonyl proteins (Table 1).

A significantly lower level of sulfhydryl proteins was found in the lens of diabetic patients compared to levels in 